\title{
An Indonesian EFL Student's Perception and Experiences in repeating English Language Proficiency Test
}

\author{
Wolter Parlindungan Silalahi' ${ }^{1}$, Friska Ria Sitorus ${ }^{2}$ \\ ${ }^{1}$ Institut Agama Kristen Negeri Tarutung, Indonesia \\ ${ }^{2}$ National Dong Hwa University, Taiwan \\ silalahiwalter1@gmail.com,Friskasitorus969@gmail.com
}

\begin{abstract}
This work aims to investigate an Indonesian EFL student's perceptions and experiences in repeatedly doing standardized English language proficiency test: TOEIC (Test of English for International Communication) and TOEFL (Test of English as a Foreign Language). This standardized test has a significant role in the academic and professional lives of students (Anam, 2019); it contributes positively to students' language proficiency and their future employment if they have higer and valid score in the test (Hsieh, 2017). This present study interviewed an Indonesian EFL student at a National University in Taiwan running an international program. The study participant passed the exam, but she did it repeatedly before she could pass it. This study used a qualitative phenomenological approach with an in-depth interview. The relevant findings illustrate that the participant reveals the reasons for failing the test: lack of self-awareness, lack of selfconfidence, and the distance of the test venue from her dormitory. On the contrary, she passed the test by doing online simulation exam individually and modifying her study skills while preparing for the test. The failure process had a positive impact on her in making her to know her ability.
\end{abstract}

\author{
Keywords \\ repeated exam English language \\ proficiency, 巴Lstudent
}

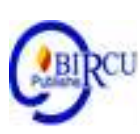

\section{Introduction}

Speaking as EFL is demanded to be learned by all of the learners. It is a particular way to express an idea to other people, speak without stuttering and establish the unbiased instruction during a communication. Speaking is a pleasant activity not only due to the ease of using it in extending, sharing and collaborating with others but also to the chance of individuals, particularly students, to communicate with English native or non-native speaker. Therefore, in everyday's life, everyone has to be able to communicate in oral form in order to involve into an interaction among people around. Moreover, it is an indirect form of obligation for any individuals to master speaking skill for their purpose to establish a social relationship among the society which is very essential in life (Wahyuni et al, 2019). The university requires EFL students to pass certain courses in placement exams in order to place them in the appropriate levels. Generally, the placement system is based on the level of students'ability which is evaluated through a communicative approach. The system expects students to be good at English Language for use in classroom communication; students are required to improve their listening and speaking skills in English Language (Johnson, 1997). Essentially, EFL students build their knowledge of English through reading, listening, writing, and speaking. This method of learning is called "constructivism", which is based on the active contribution of learners in successfully communicating to master several English skills. Students' attitudes are an integral part that determines the success of their learning and also an important component in the pedagogy 
of EFL (English as a foreign language) (Jamal \& Jamal, 2014). Communicating practically with English Language both in the classroom and in their daily lives would improve students' ability in studying EFL. It brings out the reality of the learning environment (Life, 2011).

Among all the four skills (listening, speaking, reading, and writing), speaking seems intuitively the most important one. It is believed that people who know a language are referred to as 'speaker' of that language as if speaking includes all other skills (Rahmati, 2019). Using language appropriately does not mean mere correct phonology, morphology, syntax, and semantics, but involves pragmatic knowledge or, to be more specific, cultural knowledge to avoid misunderstandings or communication breakdowns (Ibrahim \& Maniam, 2020). Furthermore, cultural variation indicates that Asian students are motivated to study EFL. For instance, Korea, China, and Japan are often seen as natural market groups for EFL education in both curriculum development and instructional approaches (Life, 2011). Indeed, having an access to communicate and collaborate with western culture helps to improve the students' linguistic skills. Students' experiences also influence their cognitive, metacognitive, and affective factors for studying EFL (Johnson, 1997). EFL students' anxiety, ability to identify specific coping techniques, and strategies have an important role to play in improving their English Language profieciency (Jing \& Junying, 2016).

Mourtaga in Al-Hidabi et al (2020) explained that the important issue and the only motivation for students in studying English language are to pass the final exams in order to move to the next level. Students' perception and insight influence what they attribute to the cause of their failure or success in exams (Jeon, Shafran, Breitfeller, Levin, \& Rosé, 2019). Asian students take the blame for their failure and attribute success to luck (Bonyadi, 2019). For instance, an Asian student attributed her failure in an exam toanxiety, health problems, and lack of proper learning. Anxiety stands out as the most cited reason for failure in exams (Bonyadi, 2019). Ma \& Yodkamlue (2019) assert that Chinese university EFL students fail in EFL courses due to lack of learning facilities and less effective time in studying EFL. This affects the academic discipline, and optimism to fight for the course successfully. However, a course adviser can be very instrumental in enhancing students' success in a course. Course advisers can help to raise students' motivation and develop their full potentials (Musser, Pierre, Wilson, \& Schwartz, 2017). The demand of proficient English speaker also highly demanded in the industry due to the effect of globalization in which English language is the medium of the international communication especially in theeconomics and trade, science and technologies, politics and diplomatic and also used in military purposes too (Thirusanku \& Melor in Entika et al, 2019).

Through a qualitative phenomenological approach, this study examines Asian EFL students who are qualified to do the required courses for a Master's degree. As international students in the EFL Department they are required to pass the English language proficiency test (Toefl/Toeic) with a minimum standard score to complete their Master's degree program. Therefore, the ultimate goal of this study is to investigate the EFL students' efforts, challenges, feelings, and responsibilities in doing the test repeatedly. In essence, this study will help EFL students to stop failing the required courses and obtain the standard score. 


\section{Research Methods}

This study adopted the qualitative phenomenological approach with an in-depth interview to understand and address the causes of failure and success in courses besides deficiencies in intellectual, social, economic, behavioral, and psychological abilities. This study chooses qualitative methods obviously because the phenomenological approach seeks to explore, describe, and analyze the meaning of individual lived experience; it makes sense of it and discusses it with others (Marshall \& Rossman, 2016). Hereafter, this study aims to answer the research question: what are the student's perceptions for repeatedly doing English language proficiency test?

\subsection{Participant and Context}

An Indonesian EFL student, doing an international program at a National University in Taiwan, with the pseudonym, Miska, agreed to participate in this study. Previously, her Bachelor's major was English; then, she decided to continue her MA degree in English. Miska is twenty-six years old. Previously, she joined a cram school and started intensive English learning when she was twelve years old. At that time, she had interest in learning English. She taught English courses part time as a private teacher at elementary and senior levels. Unfortunately, she failed the English language proficiency test severally. In essence, she had taken the Toefl test three times in Indonesia, two times in Taiwan, and also the Toeic test five times in Taiwan.

\subsection{Data Collection and Analysis}

The data collection instruments consisted of interviews and diary notes of the participant; they were administered as a platform for the student to freely express her feelings and experiences in taking the repeated test. The diary notes were used to elicit her perceptions of taking the repeated exam; they were written in Bahasa Indonesia to make her easily write her feeling. This study adopted Marshall \& Rossman (2016)'s ideas in analyzing the raw data which are three steps: managing, analyzing, and interpreting data. In this process, the researchers match the dairy notes and interview results to ensure the accuracy of the participant's responses.

\section{Results and Discussion}

\subsection{Failure Causes}

Through the interview and diary notes of the participant's analysis, the researchers wrote three things that made her to fail the English language proficiency test repeatedly: lack of self-awareness, distance of exam venue, and lack of self-confidence. Essentially, she tried to take both Toefl and Toeic tests. However, she succeeded in passing the Toeic test.

The participant tried to take the exam several times, but she was distracted by herself and the environment. In essence, she did the test with pressure and fear due to it being a requirement to pursue her MA degree. She was nervous and hurridly did the exam. It affected her self-confidence to finish the test. This is also supported by the finding of Bonyadi (2019) that anxiety is part of the reason for the failure of EFL students. This is because believing in one's ability is one of the factors that determine one's success (Gobel., et al, 2013). Furthermore, the test content was divided into several parts, thus she could not focus in the listening part. At that moment, everything became messy because of the pressure during the test. She remarks that: 
"I was too afraid to fail. I tried to answer the questions that were inaccurate because I was under pressure. I still remember I couldn't focus when I took the Toefl exam several times, although I had practiced a lot before taking the test".

Besides, the distance of the exam venue from her dormitory exhausts her; she travelled from her dormitory to the venue. Because the exam was done in a different city, she had to leave earlier. She could not stay in a hostel due to financial constraint. Therefore, she was not stable to start the test. This unconsciously impacts her physicallly to perform well. Furthermore, the English language proficiency test included ETS (Educational Testing Service) that was held nation wide at different venues for each period. She notes that:

"I have to take a train for approximately three hours to get to the venue. I got lost finding the exam building because it was unfamiliar to me. This confiscated my enthusiasm. Physically I was tired, but I had to answer the entire questions to get the pass score. It disturbed my concentration during the test. However, I felt comfortable, calm, and confident when I took the Toeic test held at my university. So, I could get enough rest before taking the test and did not rush to reach the site. I was able to complete the test quietly and finally passed it".

On the other hand, she lacked self-awareness regarding the English language proficiency test. At the beginning, she tried the Toefl test several times but failed. At that time, she thought it was easier to pass. Then, she did not know her capability. It took her a long time to know herself, her ability and competence in English language proficiency. Ultimately, she found a way to break her limits.

\subsection{Perception of Failure and Repeated Test}

As indicated in her first failure of the English language proficiency test, she was disappointed because she was not intelligent enough to answer the whole questions of the test. Moreover, the failure continued for several times. This situation took her on selfreflection, both negatively and positively. She blamed herself for not being able to reach the pass mark; she felt ashamed and got tired of doing it repeatedly.

"I felt insecured because I failed several times. Although, I prepared well for the English language proficiency test; I even modified my learning style so I could pass. Unfortunately, I felt so small because I failed several times (Miska)."

Hereafter, she sacrificed several things including time, finances, feelings, and it influenced her mentally. She felt all of her efforts were in vain because she could not pass. She was afraid to fail and not to pursue her Master's degree.

"I learned a lot through my failure. Then, I spent more time studying and searching for much information regarding English language proficiency; I downloaded a lot of learning materials for free. Since then, I started enjoying myself in learning and understanding more tips and tricks to succeed in the Toeic test. Eventually, I found that I was not able to do the Toefl test, but Toeic was easier for me (Miska)."

The participant had to assert that accidentally, during the preparation process and her failure experience, she learned to explore her abilities, until she found a way to succeed in the test. The path of gaining success in learning is to be self-motivated and take responsibility for your learning (Gobel., et al, 2013). On the contrary, her failure does not mean she was incapable. She failed because she chose the wrong English language proficiency test. This experience brought her into the process of knowing herself deeper. 


\subsection{Pedagogical Effort to Succeed}

The different learning methods have a positive influence on the participant's English language improvement. Through every single failure, she modifies her preparation method, such as learning the grammatical tricks in language proficiency, making small notes that are convenient to take anywhere, reviewing a few questions every night. Besides, she was active in doing online simulation exam for free; it gave her overwhelmingly positive tips to control her emotions, have self-confidence, and time management while working on each item. This is closely related to the ideas of Gobel., et al (2013) that effort and study skills are the most important factorsfor EFL students to obtain success. The study participant began to instill assertiveness and discipline to study and also set a goal of taking the exams every month. She did it in February, March, April, June, and July. In July, she passed with a high score, above the accepted grade for international English test (Atmojo, 2018).

\section{Conclusion}

The international students' program has a policy that foreign students must pass Toefl and Toeic tests as a requirement to enhance their English language proficiency and to secure employment in the future (Hsieh, 2017). It encourages students to improve their English skills by going through the path of failure, and then learning to get success. Besides, the preparation process of the examination makes students to become mature individuals to face challenges mentally in order to compete in the technology era that is facilitated by English. Individual motivation and self-confidence help students to take responsibility for their learning (Gobel., et al, 2013). Therefore, failure means a process of learning more about one's interest and how to achieve the ultimate goals of learning.

As experienced by Miska, after several failures in the Toefl/Toeic exam, she found a way to break her limits to pass the exam; she better established a link of learning goals through reflections (Hsieh, 2017). She spent much money and time during her failure (Bonyadi, 2019). It became a challenge for her as Asian student, non-native English speaker to pass the exam (Anam, 2019). It is suggested that students should know their ability, strength and weaknesses in order to easily figure out their failure which would enable them to succeed in their learning process.

\section{References}

Al-Hidabi, D. A., et al. (2020). Benefits and Challenges in Utilizing E-Portfolio among Ucas Students' EFL Classes in Palestine. Budapest International Research and Critics in Linguistics and Education (BirLE) Journal, 523-530.

Anam, M. K. (2019). The Impact of Vocabulary Depth and Breadth To The Toefl Reading Subtest in IAIN Kediri. International Journal of Language Education, 49-57.

Atmojo, A. E. (2018). Studetns' Problem on S-V Agreement In Toefl and Their Proposes Solutions. Jurnal Bahasa dan Sastra, 169-175.

Bonyadi, A. (2019). Failing a Course: A Diary Case Study of an Iranian EFL Student. The Journal of Asia TEFL, 1376-1384.

Entika, H. S. A., et al. (2019). The Importance of Immediate Constructive Feedback on Students' Instrumental Motivation in Speaking in English. Britain International of Linguistics, Arts and Education (BIoLAE) Journal, 1-7.

Gobel, P., Thang, S. M., Sidhu, G. K., Oon, S. I., \& Chan, Y. F. (2013). Attributions to Success and Failure in English Language Learning: A Comparative Study of Urban and Rural Undergraduates in Malaysia. Asian Social Science, 53-62. 
Hsieh, C. N. (2017). The Case of Taiwan: Perceptions of College Students Aboutthe Use of theTOEIC®Tests as a Condition of Graduation. United States: ETS Research Report.

Ibrahim, A., Maniam, M, (2020). A Review Article of the Pragmatics-Based-Curriculum in EFL Context: Focus on the Curriculum in Iraq. Budapest International Research and Critics in Linguistics and Education (BirLE) Journal, 1065-1073.

Jamal, D. A., \& Jamal, G. A. (2014). An Investigation of the Difficulties Faced by EFL Undergraduates in Speaking Skills. Journal of English Language Teaching, 19-27.

Jeon, B., Shafran, E., Breitfeller, L., Levin, J., \& Rosé, C. P. (2019). Time-series Insights into the Process of Passing or Failing Online University Courses using NeuralInduced Interpretable Student States. Proceedings of The 12th International Conference on Educational Data Mining (pp. 330-335). Canada: Universite du Quebec a Montreal.

Jing, H., \& Junying, Z. (2016). A Study on Anxiety in Chinese EFL University Students. Journal of Canadian Center of Science and Education, 179-184.

Johnson, C. R. (1997). A Mexican Project With University Academic At-risk English as a Foreign Language Students. Mexico: Educational Resources Informatuon Center (ERIC).

Life, J. (2011). Motivation and EFL University Students in North-East Asia . Asian EFL Journal, 11-41.

Ma, X., \& Yodkamlue, B. (2019). The Effects of Using a Self-developed Mobile App on Vocabulary Learning and Retention among EFL Learners. PASAA, 165-205.

Marshall, C., \& Rossman, G. B. (2016). Designing Qualitative Research. United States of America: Sage.

Musser, T., Pierre, T. S., Wilson, D., \& Schwartz, M. (2017). Experiences of Male Undergraduates That Lead to Academic Failure. Nacada Journal, 87-98.

Rahmati, M. (2019). The Effect of Task-Based Syllabus on Iranian EFL Learners. Budapest International Research and Critics in Linguistics and Education (BirLE) Journal, 32-43.

Wahyuni, S., et al. (2019). Critical Thinking Skills: British Parliamentary Debate System to Improve English as Foreign Language (EFL) Students' Critical Speaking. Budapest International Research and Critics Institute-Journal (BIRCI-Journal), 429433. 